\title{
Señales en el camino
}

La música es un ruido que piensa.

Victor Hugo

Le pido a un libro que cree en mí la necesidad de lo que me ofrece.

Jean Rostand

El comienzo de toda ciencia es la sorpresa de que las cosas sean lo que son.

Aristóteles

La obra de arte no es un reflejo, la imagen del mundo, sino que está hecha "a imagen del mundo".

Eugene Ionesco

La vida está hecha de ilusiones. Algunas de ellas tiene éxito. Son éstas las que constituyen la realidad.

Jacques Audiberti

La imaginación es el reino de lo real, y lo posible es una de las provincias de lo real.

Charles Baudelaire 
Por sí misma, la vida es una cita.

Jorge Luis Borges

No somos capaces de contemplar sino aquello que hemos soñado.

Gaston Bachelard

Respetamos la razón, pero amamos nuestras pasiones.

Emile Chartier Alain

El sabio no es aquel que construye las respuestas verdaderas; es el que hace las preguntas verdaderas.

Claude Levi-Strauss

Pensamos a partir de lo que escribimos y no lo contrario.

Louis Aragon

Todo hombre es sensible cuando es espectador. Todo hombre es insensible cuando actúa.

Emile Chartier Alain

Tantas manos para transformar el mundo, y tan pocas miradas para contemplarlo.

Louis Poirier Gracq

Las convicciones son enemigos más peligrosos de la verdad que de la mentira.

Friedrich Nietzsche

Conocer no es asunto de demostrar ni de explicar. Es acceder a la visión.

Antoine de Saint-Exupéry 
La mejor manera de aprender a conocerse es intentar comprender a los otros.

André Gide

Las palabras, es evidente, son la droga más utilizada por la humanidad.

Rudyard Kipling

La imaginación no más que el sujeto trasladado a las cosas.

Gaston Bachelard

Juzgaremos mejor a un hombre por lo que sueña que por lo que piensa.

Victor Hugo

La sabiduría no es una cuestión de tiempo, es una cuestión del corazón y el corazón no está en el tiempo.

Christian Bobin

Ochenta años es la edad de la pubertad académica.

Paul Claudel

Cuando un filósofo te responde, no comprendes ni siquiera lo que habías preguntado.

André Gide

Explicar un hecho es unirlo a otro.

Jorge Luis Borges

Es mediante el objeto que el sujeto tiene la mayor posibilidad de profundizar en sí mismo.

Gaston Bacherlard 
Los espejos harían bien en reflexionar antes de reflejar las imágenes.

Jean Cocteau

Lo que envejece a una obra, lo que la devalúa, lo que la posteridad deja de lado, es justamente aquello que el autor más apreciaba.

Roger Martin du Grande

La lectura es una felicidad que requiere más inocencia y libertad que análisis.

Maurice Blanchot

La verdad surge más fácilmente del error que de la confusión.

Francis Bacon

Lo que sabemos no es nuestro.

Marcel Proust 